DOI https://doi.org/10.18551/rjoas.2018-08.19

\title{
THE EFFECT OF MANAGERIAL ABILITY ON FIRM PERFORMANCE WITH EARNING MANAGEMENT AS INTERVENING VARIABLE
}

\author{
Adhiapsari Ni Made Anom \\ Department of Accounting, Faculty of Economics and Business, University of Airlangga, \\ Surabaya, Indonesia \\ E-mail: ai.adhiapsari@gmail.com
}

\begin{abstract}
This study aimed to examine the effect of managerial ability on the firm's performance with earnings management as intervening. managerial ability analyzed using Data Envelopment Analysis, firm's performance measured using return on assets, while for the earnings management proxy by discretionary accruals using The Modified Jones models. The sample in this research were 99 consumer goods manufacture companies listed on the Indonesia stock exchanges for the period 2014-2016. The results showed that managerial ability have a significant effect on firm performance and earnings management has a direct influence on it.
\end{abstract}

\section{KEY WORDS}

Managerial skills, managerial ability, firm performance, earning management, discretionary accruals, data envelopment analysis.

Manipulation of financial statements ever conducted by PT Kimia Farma in 2001, proves that the practice of manipulation of financial statements remains done by the corporate in Indonesia. Manipulation practices often occur because the company is required to meet the needs of corporate stakeholders in maintaining a company. In addition, the company must also be able to develop its company in order to compete with other companies to achieve competitive advantage. Growth and development of the company can not be separated from the role of a manager.

Managers of companies that generate high profitability also have a high knowledge. Athanasios et al. (2014) states that knowledgeable management to generate high profitability means having an understanding of the company's operational mechanism. Good financial performance is one of the main objectives of the company because financial performance becomes one of the aspects seen by investors in measuring how good and efficient management in operating the company.

Stakeholder theory proposed by Freeman (1984) states that managers are obliged to run the company's operations and meet the needs of the company and able to provide added value for investors and meet the needs of other corporate stakeholders. The relationship between managerial skills and firm performance has long been ignored with the assumption that managers are largely homogeneous entities that follow the company's main objectives (Bamber et al., 2010). The statement was opposed by Djuitaningsih and Rahman (2012) and began to examine the impact of managerial skills on company performance. The research gives result that managerial skill have positive effect to company performance as measured by company profitability.

The agency theory by Jensen and Meckling (1976) explains that there is a difference of interest between the management (agent) and the owner (principal) so that the agency problems arise. The problem provides an opportunity for managers to act opportunistically, for personal gain. One way that managers can do is to take a deviant action in the process of preparing financial statements.

Andreou (2015) states that a manager with high skills will tend to avoid actions that would damage his reputation. However, a skilled manager may also be able to degrade the company's performance by committing a fraudulent act. Demerjian et al. (2012) finds that higher-ability managers have a drive to improve earnings reporting by leveraging higher skills than their counterparts with accrual profit management. It is different from Graham et al. 
(2005) that reputable managers will receive higher executive compensation so that they will tend to avoid profit management actions in order not to tarnish their reputation.

The impact of earnings management on the performance of the company is considered not too clear. While earnings management has been the subject of much research in recent times, the research has focused more on certain incentives or incentives that facilitate managers to manipulate earnings. The current earnings manipulation can affect a company's performance. Accrual income management is used to develop profit that will be reported so that the perusaahaan performance looks good for investors, because investors will only see the reported earnings and ignore the behavior of profit manipulation. The explanation indicates a relationship between earnings management to company performance.

The difference of this study with previous studies is the use of earnings management as an intervening variable, which is as an intermediary between managerial skills to company performance. The variable of earnings management is chosen as intervening variable by the researcher on the basis of previous research result which found a positive and significant correlation between managerial skill to earnings management and earnings management to company performance. Therefore, research needs to be done to know more clearly whether there is direct influence between managerial skill to company performance or indirect influence between two variables through existence of earnings management practice as intervening variable.

\section{LITERATURE REVIEW}

The Effect of Managerial Ability on Earning Management. Scott (2012: 434) mentions that managers have a strong impetus to ensure expectations or expectations of desired earnings are achieved. A competent manager who understands the business conditions of his company will be able to see the opportunities of the existing accruals component for earning management in order to meet his personal interests. The opportunity exists because the information the manager has is far more than the investor has. This condition is in accordance with the agency theory expressed by Jensen and Meckling (1976).

Managerial ability also relate to the context of earnings quality. Demerjian et al. (2013) examines the relationship between managerial skills and earnings quality. The quality of the intended profit is about the accrual estimate, the study concludes that a more capable manager will make better judgments and estimates than incompetent managers so that the resulting returns are qualified.

Based on the above description, the researcher develops the following hypothesis:

$\mathrm{H} 1$ : Managerial skills affect earnings management.

Effect of Earnings Management on Company Performance. The shareholder or owner will demand the company's management to have a good corporate performance. To meet the demands provided by investors and stakeholders the company's managers perform manipulation activities by choosing accounting policies with the aim of achieving certain profit targets. Earnings management conducted by corporate managers can affect a company's earnings. Profit itself is information generated from financial statements as the output of the company that can be used to measure the performance of the company and management. When earnings management can affect corporate profits, then earnings management can also affect the company's performance

Research conducted Hillegeist (2012) provides empirical evidence that the practice of earnings management conducted by the management company does not affect the performance of the company. This is because the accounting policy in the practice of earnings management practices conducted by the company is still within normal limits so as not to cause a large deviation from the actual profit generated. According to Gunny (2005), short-term earnings management measures will indeed show good corporate performance, but in the long term will hurt the company. Research conducted by Fitriyani et al. (2014) gives result that accrual earnings management influence to company performance, while real earnings management does not show any influence to company performance. To improve 
the profit and performance of the company, managers make earnings management for the company's performance in the short term will look good in the eyes of investors.

Based on the above description, the researcher develops the following hypothesis:

$\mathrm{H} 2$ : Earning management has an effect on company performance.

The Effect of Managerial Skills on Corporate Performance. Company managers are people who are selected by shareholders and have the expertise to assume shareholders' trust in managing and running the company effectively and efficiently. Managers are also in charge of making decisions that if can add value to the company then the company will progress and have a good performance. This is in line with the stakeholder theory that companies should be able to play a dual role of meeting the needs of the company itself by running daily operational activities and must be able to meet the needs of stakeholders who also contribute to the success of the company (Gray et al., 1995).

Corporate level decision-making will reflect different levels of competence from managers. As a person who knows the way a company manager should have better information about future prospects. Managers can estimate well the earnings of the company and be informed to investors or users of other financial statements. Managers can use the accrual discretion to reflect the company's performance through earnings reports (Gul et al., 2003).

Chang et al. (2010) provides evidence that capable managers will receive higher wages and affect the value and performance of the company. Andreou et al. (2015) show that a manager's ability to understand and effectively utilize company resources is an important resource that can generate competitive advantage for the company. Similarly, Holcomb et al. (2009) suggests that managerial skills can form the basis of value creation and performance gains when resources are used effectively and efficiently.

Based on the above description, the researcher develops the following hypothesis:

H3: Managerial Ability affect the company's performance.

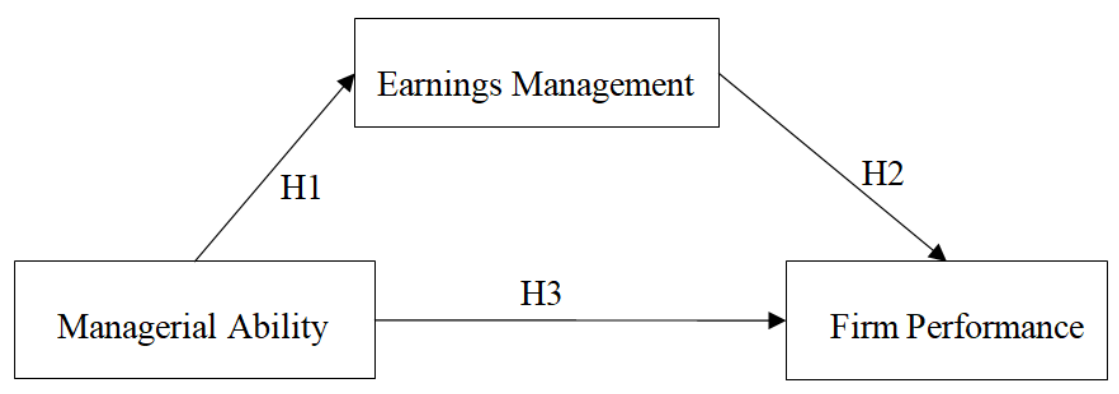

Figure 1 - Conceptual Framework

\section{METHODS OF RESEARCH}

Managerial ability are basic talent, motivation, executive personality, and reputation as another's assessment of the manager's capabilities based on available information (Demerjian et al., 2012b). In this study, managerial skills are analyzed by comparing inputs (total assets and total labor) with output (Days COGS in Inventory and Day Sales Outstanding). After determining the inputs and outputs used, then calculated the efficiency with the technique Data Envelopment Analysis (DEA) and symbolized by the symbol MA.

Firm performance is a condition of good or bad corporate finance as a reflection of the success and achievements that have been achieved by the company in a certain period. Parties responsible for good or bad company performance one of them is the manager of the company. In this study, company performance is measured by using Return on Asset (ROA). ROA can measure the overall profitability of a company's assets (Kieso et al., 2011: 222).

Scott (2012: 423) defines earnings management as a way of serving a profit that aims to maximize management utility and / or increase market value through the selection of set of accounting management procedures by management. The earnings management variable in 
this study is proxied by using discretionary accruals developed by Jones (1991) and denoted by the DA symbol. Discretionary accruals are the result of earnings engineering by managers to reduce the difficulty of detecting reported earnings through the manipulation of accounting policies with regard to accruals (Scott, 2012: 313). The Modified Jones Model is used because it is considered as the best model in detecting earnings management compared to other models and gives the strongest results (Dechow et al., 1995).

The population used in this research is a consumer goods manufacturing company listed in Indonesia Stock Exchange (IDX) for 2014 until 2016. The reason for choosing the consumer sector manufacturing company in this research is because the manufacturing sector of consumption is the most complex sector of operations than other sectors and also in terms of business finance, the sector generates transaction value from a large product or output sale so as to better reflect how the manager's efficiency in managing inputs to outputs and also management more easily seizes the opportunity for earnings management.

Sample selection in this research using purposive sampling technique. The criteria used by researchers in the selection of samples are as follows:

- Consumer manufacturing companies listed on the Indonesia Stock Exchange in the period 2014-2016, not including companies that experienced delisting because they do not meet companies listed on the Stock Exchange in the period 2014-2016;

- Consumer goods manufacturing company that issues the full annual financial statements and denominated in Rupiah in the period 2014-2016, which includes the annual report and complete audited financial statements.

\section{RESULTS OF STUDY}

Data Envelopment Analysis. The following table 1 shows the classification of managerial efficiency efficiency for manufacturing companies selected to be sampled in the period 2012-2014 based on the results of Data Envelopment Analysis:

Table 1 - Classification of Efficiency of Managerial Skills

\begin{tabular}{llllll}
\hline UKE Score & Classification & 2014 & 2015 & 2016 & Total \\
\hline 1 & Efficient & 2 & 2 & 2 & 6 \\
$<1$ & Not efficient yet & 31 & 31 & 31 & 93 \\
\hline Total Firm & & 33 & 33 & 33 & 33 \\
\hline
\end{tabular}

Based on table 1 above, companies categorized as efficient companies or have MAScore equal to $1(100 \%)$ a number of 6 companies and the rest of 93 companies entered in the category not yet efficient with MA-Score less than $1(100 \%)$.

Managerial skills affect earnings management. The value of the managerial ability regression coefficient shows a positive value of 0,517 , this indicates if the managerial skill is increased once, then the DA value will increase by 0.517 times and vice versa assuming the other independent variables are considered constant.

Table 2 - Managerial Ability (MA) - Earning Management (DA)

\begin{tabular}{|c|c|c|c|c|}
\hline \multicolumn{5}{|l|}{ Coefficients } \\
\hline \multirow{2}{*}{ Model } & Unstandardized Coefficients & Standardized Coefficients & $\mathrm{t}$ & Sig. \\
\hline & B $\quad$ Std. Error & Beta & & \\
\hline (Constant) & ,018 & & ,573 & ,568 \\
\hline MA & ,040 & ,517 & 5,943 &, 000 \\
\hline
\end{tabular}

From the results of hypothesis testing using $t$ test value that the significance value of 0.000 is smaller than 0.05 with a confidence value of $5 \%$, then $\mathrm{H} 1$ accepted that managerial skills affect the earnings management.

The results of this study prove that managerial ability significantly influence managers to practice earnings management. Managerial skills show that managers of a company are reliable and have high competence in making decisions so as to lead the company to a high 
level of corporate resource management efficiency. Managers with these criteria will be able to make value-added decisions for the company.

The results of this study indicate that managers who are reliable and have high competence may be doing earnings management. Based on agency theory, agency conflict can not be avoided. the existence of information asymmetry and the difference of interests between the shareholder and the manager (agency theory), so capable managers can flexibly to take advantage of opportunities on the accruals for the sake of personal interests Agent and principal will continue to have a tendency to emphasize its own benefits. The actions of managers also can not be directly observed by shareholders. In this condition the manager has hidden information that can be exploited for the manager's personal interest.

Although no matter how small a manager is, earnings management practices can not be avoided. Managers will still have the drive to benefit themselves and benefit the company by manipulating earnings. The results of this study in accordance with research conducted by Isnugrahadi and Kusuma (2009) and Purwanti (2012). Both of these studies provide results that managerial skills have a positive and significant impact on earnings management.

Earning management has an effect on firm performance. The value of earnings management regression coefficient (DA) of 0.949 , this shows if the earnings management increased once, then the value of ROA will increase by 0.949 times and vice versa assuming other independent variables are considered constant.

Table 2 - Earnings Management (DA) - Firm Performance (ROA)

\begin{tabular}{llllll}
\hline Coefficients & & & & \\
\hline Model & \multicolumn{2}{l}{ Unstandardized Coefficients } & Standardized Coefficients & t \\
& B & Std. Error & Beta & & \\
\hline (Constant) &,- 007 &, 005 & & $-1,548$ &, 125 \\
DA &, 983 &, 033 &, 949 & 29,588 &, 000 \\
\hline
\end{tabular}

From the results of hypothesis testing using $t$ test value that the significance value of 0.000 is smaller than 0.05 with a confidence value of $5 \%$, then $\mathrm{H} 2$ accepted the earnings management has a positive effect on firm performance.

The results show that earnings management practices with high levels of manipulation can not improve company performance significantly. Company managers strive to improve company performance by manipulating their profits. However, the company will manipulate earnings within normal limits because the company does not want to take big risks.

Based on agency theory, earnings management arises because of agency conflict between agent and principal. Company managers as much as possible try to give the best company performance so as to gain the trust of shareholders to invest. As for the shareholder of the company's performance today is a benchmark to assess whether the company can receive benefits for it. The emerging agency issues encourage corporate managers to practice earnings management. The existence of information asymmetry makes managers look for loopholes to manipulate earnings. The results of this study in accordance with research Fitriyani (2014) provide empirical evidence that the practice of earnings management accruals affect the firm performance. Management will choose certain methods to earn profits that match their motivation. This will affect the quality of performance reported by management.

Managerial ability affect the firm performance. The direct effect of PS given to CS is 0.236 , whereas the indirect effect of PS to EG is the multiplication of beta value of PS to EG with beta value of EG to CS ie: $-0.455 \times 0.763=-0.347$. Then the total effect given by PS to CS is direct influence plus indirect effect that is: $0,236+(-0,347)=-0,111$. Based on the results of the calculation is known that the value of direct influence of 0.236 and indirect influence of -0.111 which means that the value of direct influence is greater than the value of indirect influence, these results indicate that directly PS has an influence on CS. Then H3 can be accepted that managerial ability affects the firm performance.

The results of this study prove that a capable manager in running the company's operational activities will significantly improve the performance of the company so that the 
firm performance looks good in the eyes of investors and other stakeholders in the company. High competence managers will be more able to support and open up wide opportunities for companies to continue to grow and develop so that companies are able to compete with other companies. Managers who are reliable and have a high ability will be able to manage and utilize the resources of the company efficient to produce maximum output in line with expectations. Efficient enterprise resource management will bring the company's performance into a better and able to provide added value to the company's stakeholders.

Table 3 - Managerial Ability (MA) - Firm Performance (ROA)

\begin{tabular}{llllll}
\hline \multicolumn{2}{l}{ Coefficients } & & & \\
\hline Model & Unstandardized Coefficients & Standardized Coefficients & S & \\
& B & Std. Error & Beta & \\
\hline MA &,- 007 &, 018 &,- 014 &,- 365 &, 717 \\
DA &, 990 &, 039 &, 956 & 25,407 &, 000 \\
\hline
\end{tabular}

Stakeholder theory states that as a manager must be able to play a double role as a person who runs the company's operational activities and must also be able to meet the needs of corporate stakeholders. This theory supports the results of this study. The needs of the company's stakeholders are the firm performance. The company's stakeholders will see and measure a company's success from the company's performance. The performance of a well-performing company shows that the company has succeeded in managing capital invested by stakeholders in the company. The results of such investments will benefit them. Decisions made by competent managers more reflect professional judgment of managers who not only benefit themselves. The results of this study are in line with the research conducted by Chang et al. (2010) and Andreou et al. (2015)

\section{CONCLUSION}

Managerial ability has a significant effect on earnings management. Managers who are reliable and have a high competence may be doing earnings management. Although no matter how small a manager is, earnings management practices can not be avoided. Managers will still have the drive to benefit themselves and benefit the company by manipulating earnings. Earnings management has a significant effect on company performance. Great earnings management practices as well as small earnings management practices have a significant effect on the performance of the company. The agency problem that arises in the company encourages the company manager to practice earnings management. Managerial ability have a significant effect on firm performance. Managers who are competent in running the company's operations will be able to improve the firm performance so that the company's performance looks good in the eyes of investors and other stakeholders in the company.

\section{REFERENCES}

1. Agustia, D. 2013. Pengaruh Faktor Good Corporate Governance, Free Cash Flow, dan Leverage Terhadap Manajemen Laba. Jurnal Akuntansi dan Keuangan, 15(1), 27-42.

2. Anshori, Muslich dan Sri Iswati. 2009. Buku Ajar Metodologi Penelitian Kuantitatif. Surabaya: Fakultas Ekonomi dan Bisnis Universitas Airlangga.

3. Andreou, P. C., Ehrlich, D., Karasamani, I., \& Louca, C. 2015. Managerial ability and firm performance: Evidence from the global financial crisis. Available at SSRN.

4. Bamber, L. S., Jiang, J., \& Wang, I. Y. 2010. What's my style? The influence of top managers on voluntary corporate financial disclosure. The Accounting Review, 85(4), 1131-1162.

5. Chang, Y. Y., Dasgupta, S., \& Hilary, G. 2010. CEO ability, pay, and firm performance. Management Science, 56(10), 1633-1652. 
6. Cupertino, C. M., Martinez, A. L., \& da Costa, N. C. 2015. Earnings manipulations by real activities management and investors' perceptions. Research in International Business and Finance, 34, 309-323.

7. Dechow, P. M., Sloan, R. G., \& Sweeney, A. P. 1995. Detecting earnings management. Accounting review, 193-225.

8. 1996. Causes and consequences of earnings manipulation: An analysis of firms subject

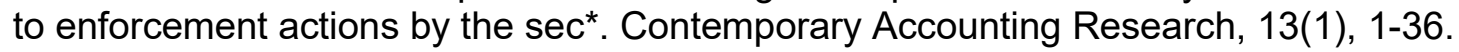

9. Demerjian, P., Lev, B., \& McVay, S. 2012a. Quantifying managerial ability: A new measure and validity tests. Management Science, 58(7), 1229-1248.

10. 2012b. Managerial Ability And Earnings Management. Washington University.

11. 2013. Managerial Ability and Earnings Quality. The Accounting Review, 88(2), 463-498.

12. Djuitaningsih, T., \& Rahman, A. 2012. Pengaruh Kecakapan Manajerial Terhadap Kinerja Keuangan Perusahaan. Media Riset Akuntansi, 1(2).

13. Fitriyani, D., Prasetyo, E., Mirdah, A., \& Putra, W. E. 2014. Pengaruh Manajemen Laba terhadap Kinerja Perusahaan dengan Kualitas Audit sebagai Variabel Pemoderasi. Jurnal Dinamika Akuntansi, 6(2).

14. Francis, J., Huang, A. H., Rajgopal, S., \& Zang, A. Y. 2008. CEO Reputation and Earnings Quality*. Contemporary Accounting Research, 25(1), 109-147.

15. Freeman, R. E. 1984. Strategic management: A stakeholder perspective. Boston: Pitman.

16. Ghozali, Imam. 2013. Aplikasi Analisis Multivariate dengan Program IBM SPSS 21 Update PLS Regresi. Semarang: Badan Penerbit Universitas Diponegoro.

17. Graham, J. R., Harvey, C. R., \& Rajgopal, S. 2005. The economic implications of corporate financial reporting. Journal of accounting and economics, 40(1), 3-73.

18. Gunny, K. A. 2005. What are the consequences of real earnings management?. Citeseer.

19. Healy, P. M. 1985. The effect of bonus schemes on accounting decisions. Journal of accounting and economics, 7(1), 85-107.

20. 1996. Discussion of a Market-based Evaluation of Discretionary Accrual Models. Journal of Accounting Research 34.

21. 1999. A review of the earnings management literature and its implications for standard setting. Accounting horizons, 13(4), 365-383.

22. Holcomb, T. R., Holmes, R. M., \& Connelly, B. L. 2009. Making the most of what you've got: managerial ability as a source of resource value creation. Strategic Management Journal.

23. Isnugrahadi, I., \& Kusuma, I. W. 2009. Pengaruh Kecakapan Manajerial Terhadap Manajemen Laba dengan Kualitas Auditor sebagai Variabel Pemoderasi. Simposium Nasional Akuntansi XII, Palembang.

24. Jensen, M. C., \& Meckling, W. H. 1976. Theory of the firm: Managerial behavior, agency costs and ownership structure. Journal of financial economics, 3(4), 305-360.

25. Jones, J. J. 1991. Earnings management during import relief investigations. Journal of accounting research, 193-228.

26. Kieso, Donald E., Jerry J. Weygandt, dan Terry D. Warfield. 2011. Intermediate Accounting. IFRS Edition, Volume 1. United States of America: John Wiley \& Son, Inc.

27. Li, H. 2014. Top Executives' Ability and Earnings Quality: Evidence from the Chinese Capital Markets. International Journal of Financial Research, 5(2), p79.

28. Malmendier, U., 2008. Superstar ceos: National Bureau of Economic Research.

29. Noreen, E. W., Brewer, P. C., \& Garrison, R. H. 2014. Managerial Accounting for Managers: McGraw-Hill Higher Education.

30. Reverte, C., \& Guzman, I. 2010. The predictive ability of relative efficiency for future earnings: an application using data envelopment analysis to Spanish SMEs. Applied Economics, 42(21), 2751-2757.

31. Scott, William R., 2012. Financial Accounting Theory. 6th Edition. Toronto: Pearson Canada Inc.

32. Sulistyanto, Sri. 2008. Manajemen Laba: Teori dan Model Empiris. Jakarta: Grasindo. 